\title{
ENTREVISTA COM EDIVÂNIA GRANJA DA SILVA OLIVEIRA: ETNODIVERSIDADE E FORMAÇÃO DE PROFESSORES
}

\author{
DOI: http://dx.doi.org/10.5965/1984317814012018176
}

A professora Edivânia Granja da Silva Oliveira é doutoranda em História Social pelo PPG em História Social DINTER UFCG/USP, Mestre em História pelo PPG/HISTÓRIA-UFCG e Especialista em História pela Universidade de Pernambuco, possui ainda, Atualização Pedagógica pela Universidade Federal do Rio de Janeiro e é Licenciada em História pela Universidade de Pernambuco. Atualmente é professora de História do IF Sertão PE, Campus Petrolina. Desenvolve pesquisa com comunidades Quilombolas e Povos Indígenas na área de História Ambiental e Educação.

1) REAI: Temos acompanhando mudanças e avanços nas pesquisas e políticas públicas voltadas à ações afirmativas em prol das questões étnicorraciais. Gostaríamos de iniciar conhecendo um pouco mais como tem sido sua atuação junto ao IFSertão e às comunidades indígenas e quilombolas. Quais questões já puderam ser cartografadas e analisadas? E quais aspectos considera importantes para futuros desenvolvimentos de pesquisas e atuação?

Profa. Edivânia: Vou tentar responder a pergunta em duas partes, a primeira falar sobre meu percurso de pesquisas com os quilombolas e indígenas e a segunda parte buscar explicitar as ações desenvolvidas pelo IF Sertão PE, que estou envolvida.

Iniciei pesquisas acadêmicas com comunidades quilombolas, especialmente a Comunidade Quilombola Conceição das Crioulas, município de Salgueiro, Estado de Pernambuco, ainda em 2008 quando ingressei através de concurso público como professora de História da Faculdade de Ciências Humanas do Sertão CentralFACHUSC, em Salgueiro/PE. E em 2010 assumi o cargo de professora efetiva de História, IF Sertão PE, também através de concurso público, com Dedicação 
Exclusiva. Continuei com estudos focados na história e cultura afro-brasileira, mas com outros quilombos, povos de terreiro e ações educativas de promoção da igualdade racial, principalmente através da criação da Comissão Permanente Projeto Cultura Afro e Indígena. É interessante pontuar que até 2012 a temática indígena praticamente não fazia parte do meu universo de pesquisa, somente no universo da sala de aula e neste ambiente surgiu a ideia de propor a duas turmas do Ensino Médio Integrado pesquisa bibliográfica sobre os atuais indígenas da Bacia do São Francisco. O projeto didático foi um sucesso, pois inicialmente o período de desenvolvimento da atividade seria durante a primeira etapa, mas com a empolgação e o interesse das turmas em pesquisar os Povos Indígenas do Sertão Pernambucano estendemos a pesquisa a todo o ano letivo. A partir deste projeto didático também passei a desenvolver interesse em aprofundar conhecimentos sobre a temática. $O$ interessante é que os alunos do Ensino Médio foram convidados a apresentar os resultados do referido projeto as turmas da modalidade de Educação de Jovens e Adultos (PROEJA) e naquela oportunidade conheci um indígena Pankará, aluno do PROEJA-Edificações, que fez um breve relato sobre a história do Povo Pankará e o Território que habitam, a Serra do Arapuá, um Brejo de altitude - área úmida com vegetação de mata atlântica em meio a Caatinga. A partir daí, visitei a Serra, conversei e conheci algumas lideranças indígenas e decidi empreender pesquisas sobre os indígenas Pankará no Mestrado e agora no Doutorado.

Compondo as minhas atividades de pesquisa relatadas, também como membro e Presidente da Comissão do Projeto Cultura Afro e Indígena passamos a divulgar ações relativas a temática negra e indígena. Vale salientar a parceria promissora com o colega, professor Herlon Bezerra, ainda em 2011. Então, passamos a planejar ações com foco na Educação Intercultural destinada aos professores quilombolas e indígenas. Criamos o projeto de Formação Inicial e Continuada (FIC) com o objetivo de reunir lideranças quilombolas e indígenas para construção do projeto de especialização intercultural no pensamento decolonial, com a realização de 07 (sete) oficinas em 2012 e 2013, nas quais definimos todo o projeto do curso, incluindo o Edital de seleção. A partir desta ação interinstitucional através da parceria do Campus Petrolina com o Campus Floresta. Destaco que, eu o colega Herlon somos lotados no Campus Petrolina, mas a oferta do FIC e do Curso de Especialização foi ofertado no Campus Floresta, no munícipio de Floresta, no Sertão de Itaparica, área 
de maior quantitativo de populações indígenas e quilombolas do Estado de Pernambuco. Além da instituição de parcerias externas com a Comissão de Professores Indígenas de Pernambuco (COPIPE), o Núcleo de Educação Quilombola de Pernambuco e o CIMI/PE (Comissão Missionária Indigenista).

Ressalto que fizemos uma pesquisa de diagnóstico da educação quilombola e indígena em Pernambuco, com a reunião de informações diversas, mas ainda falta a compilação e análises dos dados.

A educação escolar quilombola e indígena ainda carece de pesquisas e políticas públicas educacionais em áreas diversas, com questões relativas a formação de professores na perspectiva da educação intercultural diferenciada e especifica, no pensamento decolonial.

REAl: Como você avalia a implementação da Lei $11.645 / 08$, que inclui no currículo oficial da rede de ensino a obrigatoriedade da temática "História e Cultura Afro-Brasileira e Indígena", na formação de professores? Quais os caminhos percorridos e a percorrer?

Profa. Edivânia: Em 2010 o IF Sertão PE (Campus Petrolina) criou uma Comissão Permanente, denominada Projeto Cultura Afro e Indígena, que contou com a participação de 13 (treze) docentes e 01 (uma) pedagoga. Com o objetivo da aplicabilidade das Leis 10.639/03 e 11.645/08, focado na inclusão de conteúdos didáticos, no planejamento e realizações ações educativas para o combate ao racismo e a descriminação étnico-racial. Apesar de termos desenvolvido vários projetos didáticos e pesquisas com temática em tela, ainda não conseguimos efetivar a Educação das Relações Étnico-Raciais nas práticas pedagógicas dos docentes, pois as ações desenvolvidas em relação a temática foram e são realizadas por um grupo restrito de docentes e discentes. Com a intenção de ampliar as reflexões para toda a comunidade escolar será implantada o Núcleo de Estudos Afro-brasileiro e indígenas no início de 2018, com a eleição de membros internos que irão representar docentes, discentes, técnico-administrativos e membros externos, como representantes de 
associações de bairro, quilombola e indígena, no intuito de planejar e coordenar ações de promoção da igualdade étnico-racial.

REAl: Quais as principais contribuições e mudanças que você considera necessárias, no âmbito da formação de professores, para que se construa um perfil curricular voltado para uma educação intercultural descolonizante?

Profa. Edivânia: Para efetivar a educação intercultural descolonizante nos cursos de licenciaturas é primordial que seja abolido o eurocentrismo, que a Europa não seja o eixo central na base curricular, mas que busque contemplar os conhecimentos dos africanos, dos asiáticos e dos nativos/indígenas americanos, especialmente a história e cultura dos povos indígenas, quilombolas e afro-brasileiros aliado aos conhecimentos ocidentais na mesma proporção e patamar de reconhecimento teóricocientifico.

REAl: No âmbito da formação continuada de professores, como você avalia a inserção dos debates acerca das questões étnicorraciais?

Profa. Edivânia: É fundamental que em todas as modalidades de formação de professores a educação das relações étnico-raciais faça parte como conteúdo curricular e práticas metodológicas a fim de promover a equidade e a inserção dos grupos étnicos no acesso à educação e a plena cidadania.

REAl: Como você considera a inter-relação entre as Instituições de Ensino Superior e a Rede de Educação Básica no avanço destas discussões? 
Profa. Edivânia: Infelizmente ainda não existe de forma efetiva a inter-relação entre a Educação Básica e as Instituições de Ensino Superior. Há uma distância entre o universo acadêmico e as práticas escolares em todas as modalidades de educação da rede básica. Sugiro que as Instituições de Ensino Superior aprendam com os indígenas como fazer a Educação Escolar Indígena de forma efetiva, a qual buscam relacionar com a formação acadêmica, mesmo que nas Universidades com pensamento colonialista, traduzindo e (re)significando a história, articulando os saberes ancestrais com os conhecimentos curriculares da Educação da rede básica do Estado; aliando a construção participativa do currículo com a realidade e participação de cada Povo Indígena.

REAl: Para terminar, você tem algum comentário final? Alguma mensagem que queira deixar?

Profa. Edivânia: Sigamos com esperança! Que possamos formar e informar os/as futuros professores/as para que efetivem a educação promotora da igualdade, do respeito e da inserção dos grupos étnicos, especialmente os indígenas e os/as negros/as que compõem a sociedade, mas que historicamente foram excluídos, especialmente da educação no Brasil. 